УДК 536.24:536.33:697.133

\title{
ЧИСЕЛЬНІ ДОСЛІДЖЕННЯ ВПЛИВУ РАДІАЦІЙНОГО ТА КОНВЕКТИВНОГО ТЕПЛОПЕРЕНОСУ НА ТЕПЛОІЗОЛЯЦІЙНУ СПРОМОЖНІСТЬ ДВОКАМЕРНИХ СКЛОПАКЕТІВ
}

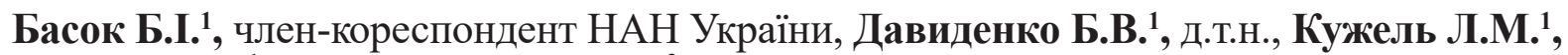 \\ Новіков В.Г. ${ }^{1}$, к.т.н., Калініна М.Ф. ${ }^{2}$, к.т.н. \\ ${ }^{1}$ Інститут технічної теплофізики НАН України, вул. Желябова, 2а, м. Київ, 03680, Україна \\ ${ }^{2}$ Національний технічний унаверситет України “Київський політехнічний інститут імені Ігоря Сікорського”, \\ пр-т Перемоги, 37, м. Київ, 03056, Україна
}

Методом чисельного моделювання досліджені закономірності теплопередачі через двокамерний склопакет зі звичайним склом, а також через двокамерні склопакети 3 низькоемісійним покриттям. Визначено їх опори теплопередачі. Отримані розрахункові дані дають можливість визначити рівні тепловтрати будівлі.

Бібл. 10, табл. 1 , рис. 7.
Методом численного моделирования исследованы закономерности теплопередачи через двухкамерный стеклопакет с обычным стеклом, а также через двухкамерные стеклопакеты с низкоэмиссионным покрытием. Определены их сопротивления теплопередаче. Полученные расчетные данные дают возможность определить уровни теплопотери здания.
Using the method of numerical modeling, regularities of heat transfer through a double glazing with plain glass and double-chambered glazed windows with a low-emission coating are investigated. Their resistance to heat transfer is determined. The results of numerical modeling made it possible to determine the heat loss levels of the building.

Ключові слова: теплопередача; віконні конструкції; чисельне моделювання; радіаційний теплообмін; конвективний теплообмін; двокамерний склопакет; низькоемісійне покриття.

\section{Bcmyn}

Енергоефективність та енергозбереження $є$ одними iз найважливіших пріоритетів соціально-економічного розвитку країни. Спроби вирішення проблеми підвищення енергетичної ефективності в Україні робилися продовж досить значного періоду часу. Було розроблено велику кількість нормативно-правових актів різного рівня (більше 250), запропоновано безліч заходів, у тому числі й з врахуванням досвіду європейських країн. Україна долучилася до Договору про Енергетичне Співтовариство та інших європейських ініціатив, де скорочення питомого споживання енергетичних ресурсів $\epsilon$ одним із найважливіших напрямів енергетичноїполітики [1]. Із прийняттям урядом України «Національного плану дій $з$ енергоефективності на період до 2020 року» [2], наша країна отримала можливість запроваджувати європейські практики планування та прогнозування розвитку енергетики, реалізації політики підвищення енегоефективності. У відповідності до [2] житлові та громадські будівлі залишаються головним пріоритетом державної політики в сфері енергоефективності. Адже саме ця сфера $є$ однією 3 найбільш енергоємних в країні, але й водночас має найбільший потенціал підвищення енергоефективності. Основним резервом економії енергоресурсів в житлово-комунальному господарстві є зниження споживання теплової енергії в будівельній галузі. Технічний стан більшості існуючих будівель та енергетичних систем не дозволяє забезпечувати необхідний рівень енергетичних характеристик будівель. Одним з варіантів вирішення проблеми енергозбереження $\epsilon$ підвищення енергоефективності будівель та споруд, а саме: застосування комплексу заходів для покращення теплоізоляційних властивостей теплоізоляційної оболонки будівель 3 проведенням термомодернізації існуючих систем, що забезпечують тепловий комфорт [3].

\section{Аналіз основних досліджень та публікацій}

Підвищення енергоефективності і теплового захисту будівель являється актуальною проблемою будівництва та архітектури. Відомо, що на віконні конструкції припадає до 40 \% тепловтрат через фасади. Для встановлення характеристик теплопередачі через двокамерний склопакет, а також вивчення його особливостей, що впливають на збільшення термічного опору двокамерних склопакетів в порівнянні з однокамерними, проводяться чисельні дослідження. Їх результати для однокамерних склопакетів представлені в роботах $[4,5]$. Результати моделювання теплообміну в міжстекловому проміжку вікна розглянуті в $[6,7]$.

\section{Постановка задачі}

В Інституті технічної теплофізики НАН України була проведена термомодернізація частини будівлі із заміною старих віконних конструкцій на сучасні склопакети. На цій основі проведено теплофізичні дослідження різноваріантних склопакетів та віконних профілів рам у відповідності до [8]. Також, на території інституту побудовано енергоефективний будинок пасивного типу, де встановлено енергоефективні віконні конструкції.

Для визначення особливостей процесу радіаційноконвективного теплопереносу через сучасні склопакети було проведено його чисельне моделювання на основі розв'язання системи рівнянь, яка включала в себе 
рівняння Нав’є-Стокса, рівняння енергії та рівняння стану для газового середовища, а також рівняння теплопровідності для скла. На внутрішніх поверхнях скла задавалися граничні умови четвертого роду з урахуванням радіаційного та конвективного теплопереносу. На зовнішніх поверхнях склопакету задавалися умови першого роду. У варіанті задачі для склопакету 3 і-покриттям на поверхнях скла характеристика покриття задавалася, як відповідна ступінь чорноти. Схема розрахункової області представлена на рисунку 1. Для чисельного розв'язання системи рівнянь було використано метод контрольного об'єму [9]. Для складання дискретних аналогів диференційних рівнянь, які описують рух газового середовища (повітря в камерах) і теп-

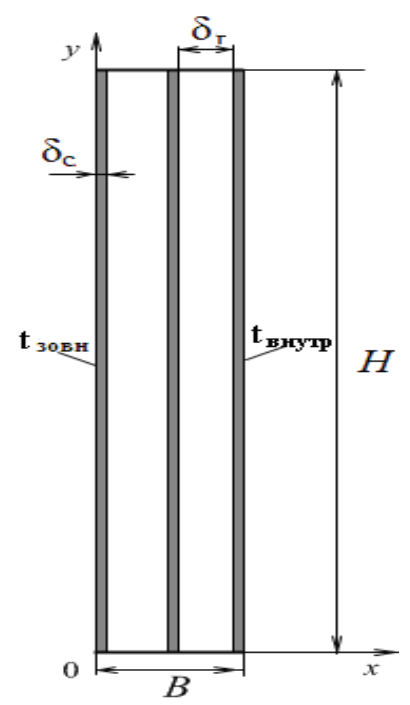

Рис. 1. Схема розрахункової області.

Результати розрахунків температурного поля та поля швидкості повітряного середовища у вертикальному перерізі двокамерного склопакета зі звичайним склом наведено на рис. 2. Розподіл температури та швидкості повітряного середовища в склопакеті зі звичайним склом наведено на рис. 3 Як видно 3 рисунків, в обох камерах склопакету спостерігається підйомно-опускна вільноконвективна течія газового середовища. У камері, що розташована біля зовнішнього скла, максимальна вертикальна швидкість становить $\mathrm{V}_{\max }=0,022 \mathrm{~m} / \mathrm{c}$, а в камері, що знаходиться ближче до внутрішнього скла $-\mathrm{V}_{\max }=0,018 \mathrm{M} / \mathrm{c}$ (рис. 3). Внаслідок невеликих значень швидкості течії лопереносу через склопакет використовувалася рознесена прямокутна різницева сітка [10].

Розглянемо, як приклад, результати розрахунку теплопереносу через двокамерний склопакет висотою $\mathrm{H}=1,08$ м і шириною $\mathrm{L}=0,75$ м. Кожне 3 трьох стекол має товщину $\delta_{\text {c }}=4$ мм. Відстані між стеклами $\delta_{\text {г }}=10$ мм. Загальна товщина склопакета $\mathrm{B}=0,032$ м. Коефіцієнт теплопровідності скла $\lambda_{c}=0,74 \mathrm{BT} /(\mathrm{M} \cdot \mathrm{K})$. Ступінь чорноти поверхонь звичайного скла без і-покриття становить $\varepsilon_{\text {c }}=0.86$. Камери склопакета заповнені повітрям. Температура поверхні внутрішнього скла, зверненої в бік приміщення, дорівнює $\tau_{\text {в }}=12,7{ }^{\circ} \mathrm{C}$, а температура зовнішньої поверхні зовнішнього скла складає $\tau_{3}=-7,5^{\circ} \mathrm{C}$.

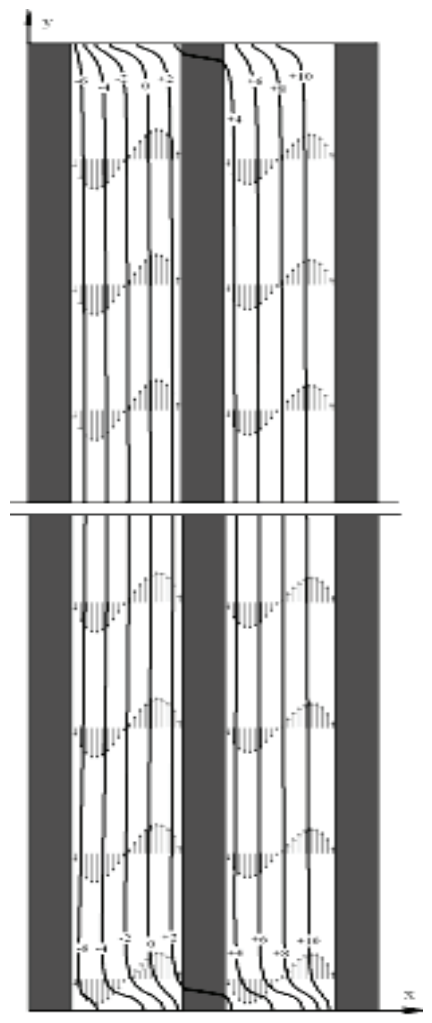

Рис. 2. Температурне поле та профілі швидкості газового середовища у вертикальному перерізі двокамерного склопакета зі звичайним склом.

в прошарках між стеклами двокамерного склопакету, конвекція не істотно впливає на теплоперенос. Тому розподіл температури по товщині газового прошарку близький до лінійного (рис. 3). Характерною особливістю такого режиму теплопереносу є також те, що ізотерми у вертикальному перерізі практично паралельні (рис. 2). Відхилення ізотерм від паралельності спостерігається лише зверху на знизу склопакету, де відбувається розворот потоку газового середовища, а напрямок його руху змінюється від підйомного до опускного.

Розподіл густини теплового потоку по зовнішній та внутрішній поверхнях цього склопакету наведено на рис. 4. 


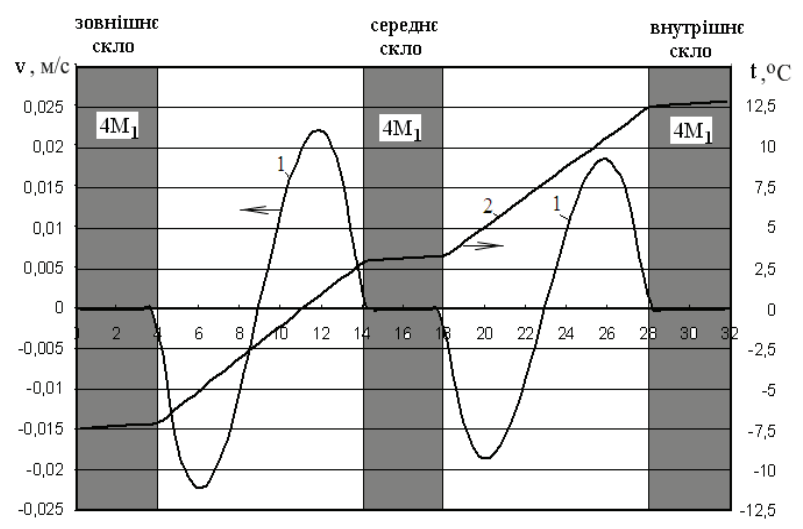

\section{Рис. 3. Розподіл вертикальної ивидкості (1) в газових прошарках і температури (2) по товщині двокамерного склопакету зі звичайним склом.}

Як видно 3 рис. 4, густини теплового потоку на обох поверхнях майже співпадають в середній частині склопакету. Максимальне значення густини теплового потоку спостерігається на верхній ділянці зовнішнього скла (крива 1) і на нижній ділянці внутрішнього скла (крива 2). Дана особливість теплопереносу через склопакет пояснюється наявністю підйомних і опускних течій в газовому середовищі всередині камер. Близько верхнього і нижнього торців склопакета відбувається зміна напрямку течії середовища. Внаслідок цього, біля однієї поверхні камери склопакета градієнти температури зменшуються, а біля протилежної - збільшуються. У середній частині склопакета градієнти температури практично не змінюються по товщині газового прошарку (рис. 3). Градієнти температури по вертикальній координаті в середній частині склопакета практично дорівнюють нулю (рис. 2). Тому теплові потоки в середній частині двокамерного склопакета однакові на зовнішній і внутрішній поверхнях. У розглянутому випадку сумарний тепловий потік через двокамерний склопакет становить $\mathrm{Q}=47,22$ Вт. При цьому на частку радіаційної складової припадає 58 \% сумарного теплового потоку в камері, що примикає до зовнішнього

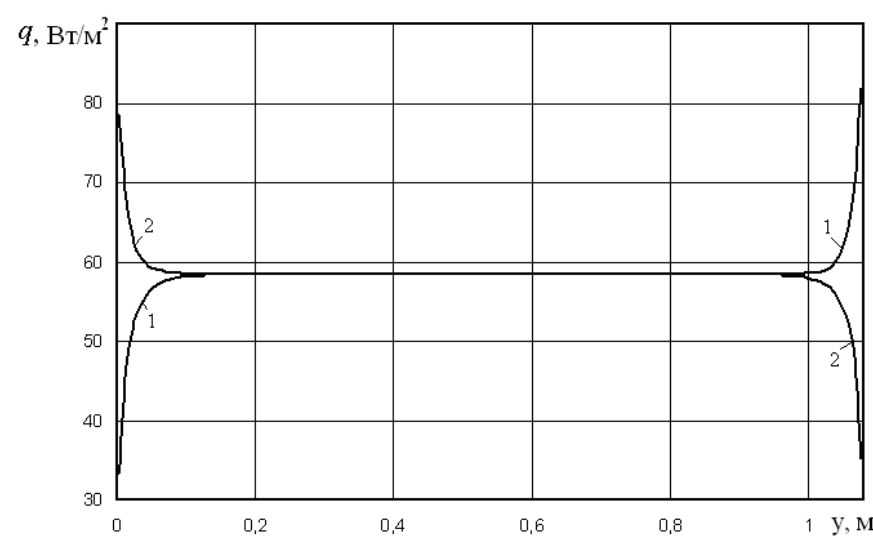

Рис. 4. Розподіл густини теплового потоку по зовнішній (1) та внутрішній (2) поверхнях двокамерного склопакету зі звичайним склом.

скла $\left(\mathrm{Q}_{r}=27,38 \mathrm{BT}\right)$, i $60 \%$ - у внутрішній камері $\left(\mathrm{Q}_{\mathrm{r}}=28,33\right.$ Вт).

Для характеристики теплоізоляційних властивостей віконних конструкцій використовується величина опору теплопередачі. В даному випадку для розрахунку опору теплопередачі використовується формула: $R=\frac{\left(\tau_{\mathrm{B}}-\tau_{\mathrm{H}}\right) H L}{Q}$. Для склопакета зі звичайним склом, що розглядається, ця величина становить $R=0,346 \mathrm{M}^{2} \cdot \mathrm{K} / \mathrm{Bт}$.

Для 3'ясування впливу низькоемісійного покриття на характеристики теплопереносу через двокамерні склопакети було проведено аналогічні чисельні дослідження двокамерного склопакета 3 м'ягким i-покриттям на внутрішній поверхні внутрішнього скла. Ступінь чорноти на цій поверхні задавався відповідно до характеристик цього покриття. Температурне поле та напрям руху газового середовища у вертикальному перерізі двокамерного склопакета 3 одним і-покриттям наведено на рис. 5. Розподіл безрозмірної вертикальної швидкості (1) в газових прошарках і безрозмірної температури (2) по товщині двокамерного склопакету з одним і-покриттям наведено на рис. 6.

Табл. 1. Порівняльні характеристики чисельного моделювання двокамерних склопакетів

\begin{tabular}{|c|c|c|c|c|}
\hline $\begin{array}{l}\text { Tип } \\
\text { склодакету }\end{array}$ & $\mathrm{q}, \mathrm{BT}$ & $\begin{array}{l}R_{\text {cksar. }} \\
\mathbf{M}^{2}: K / B T\end{array}$ & \begin{tabular}{|l} 
Частка радіа- \\
ційного потоку \\
від зага.льного \\
теп.лового пото- \\
ку, у внутрішній \\
камері, \%
\end{tabular} & $\begin{array}{l}\text { Частка радіа- } \\
\text { ційного потоку } \\
\text { від зага.льного } \\
\text { теплового пото- } \\
\text { ку, у зовнішній } \\
\text { камері, \% }\end{array}$ \\
\hline $\begin{array}{l}\text { Двокамерній, } \\
\text { 4Ml-10-4MI- } \\
\text { 10-4Ml }\end{array}$ & 47,22 & 0,35 & 60 & 58 \\
\hline $\begin{array}{l}\text { Двокамерншй } 3 \\
\text { одншм і- } \\
\text { покриттям, } \\
4 \mathrm{Ml}-10-4 \mathrm{Ml} \text { - } \\
10-4 \mathrm{i}\end{array}$ & 33,86 & 0,48 & 27 & 58 \\
\hline $\begin{array}{l}\text { Двокамерниц̆ } 3 \\
\text { двома i- } \\
\text { покриттями, } \\
4 \mathrm{Ml}-10-4 \mathrm{i}-10-4 \mathrm{i}\end{array}$ & 26,47 & 0,61 & 27 & 26 \\
\hline
\end{tabular}


Порівнявши рисунки 3 i 6 можна побачити відмінність значень швидкості в камерах склопакету максимальне значення в двокамерного склопакету 3 i-покриттям становить не в камері біля зовнішнього скла, як у випадку двокамерного склопакету без покриття, а навпаки - біля внутрішнього скла. Це свідчить про те, що і-покриття знижує рівень радіаційного теплопереносу і збільшує опір теплопередачі через внутрішню камеру. Внаслідок цього збільшується різниця між температурами протилежних поверхонь внутрішньої камери склопакета.

Аналогічні розрахункові дослідження проведені та-

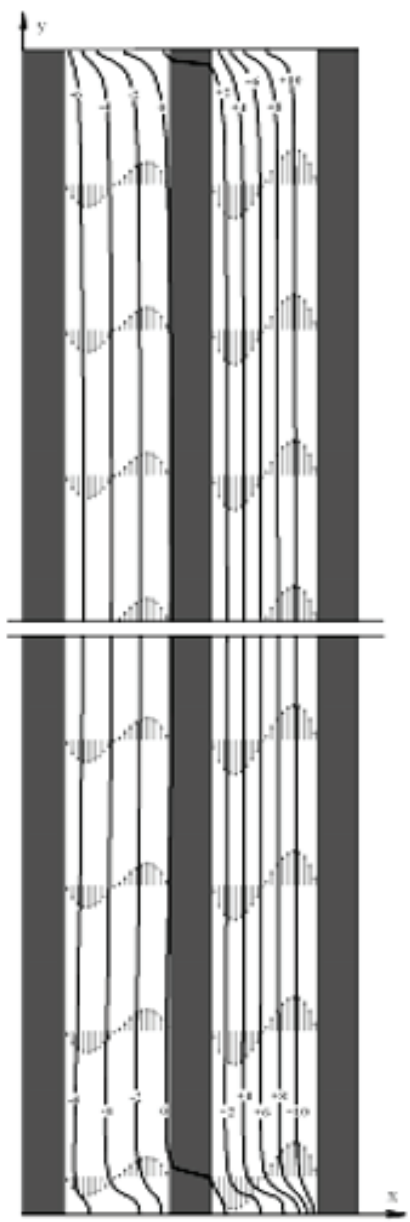

Рис. 5. Температурне поле та напрям руху ивидкості газового середовища у вертикальних перерізах в двокамерному склопакеті з одни і-покриттям.

\section{Висновки}

Проведені чисельні дослідження показали, що центральне скло в двокамерному склопакеті сприяє зменшенню конвективного теплопереносу через газове середовище за рахунок зниження швидкості вільноконвективних течій в камерах. Але більш впливово сприяє зменшенню радіаційного теплопереносу центральне скло, виконуючи функцію екрану. Завдяки нанесенню низькоемісійних покриттів на поверхні склопакету зменшується радіаційна складова тепло- кож для двохкамерного склопакету з двома і-покриттями. Розподіл швидкостей в камерах цього склопакету наведено на рис. 7. 3 результатів розрахунків випливає, що додатковий шар з і-покриття підвищує опір теплопередачі двокамерного склопакета

Порівняння характеристик двохкамерних склопакетів, що розглядалися, наведено в таблиці 1. Як видно 3 наведеної таблиці, збільшення опору теплопередачі двохкамерних склопакетів 3 низькоемісійним покриттям відбувається за рахунок зниження радіаційної складової сумарного теплового потоку через двохкамерний склопакет.

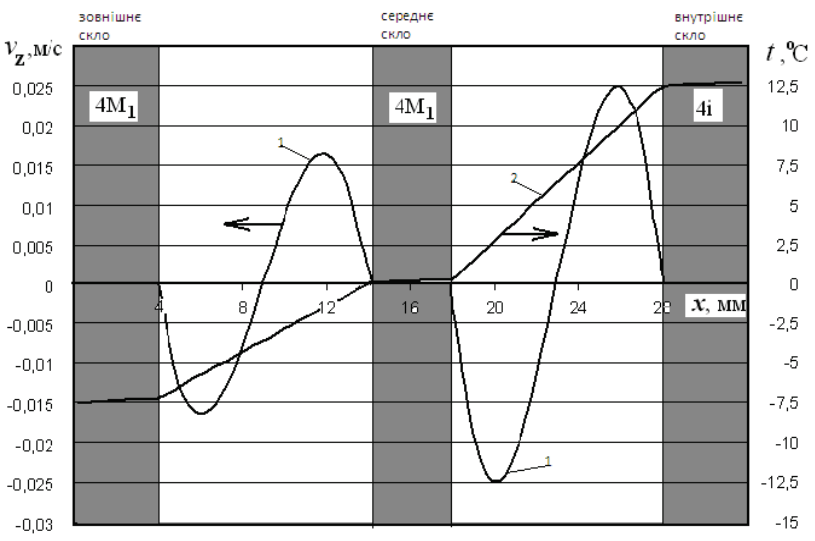

Рис. 6. Розподіл вертикальної ивидкості (1) в газових прочирках і температури (2) по товщині двокамерного склопакету з одим і-покриттям.

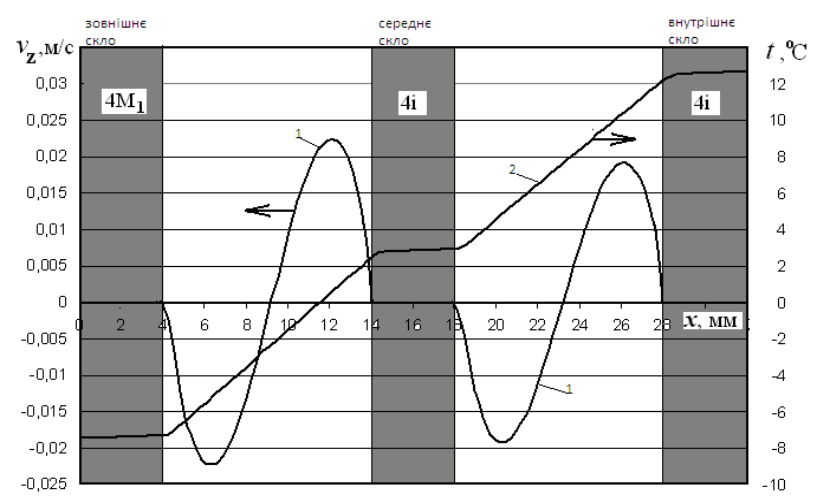

Рис. 7. Розподіл вертикальної швидкості (1) в газових прошарках і температури (2) по товщині двокамерного склопакету з 2-ма і-покриттями.

переносу. Внаслідок цього збільшується значення опору теплопередачі.

\section{ЛIТЕРАТУРА}

1. Енергоефективність у регіональному вимірі. Проблеми та перспективи. Аналітична доповідь. [Електронний ресурс] / http://www.niss.gov.ua/content/articles/ files/energoefekt-b40dc.pdf

2. Кабінет Міністрів України, постанова від 11 листопада 2015 р. № 1228-р “Національний план дій 3 енергоефективності на період до 2020 року” [Електрон- 
ний ресурс] / сайт Верховної Ради

http://zakon2.rada.gov.ua/laws/show/n0001824-15/ paran2\#n2

3. Покрашення енергетичної ефективності будівель шляхом застосування сучасних енергоефективних віконних конструкцій / Басок Б.І., Гончарук С.М., Кужель Л.М. // Збірник праць 14 Всеукраїнської науково-технічної конференції «Актуальні проблеми енергетики та екології», Одеса, ОНАХТ, 5-8 жовтня 2016 p. - C.148-152.

4. Корепанов Е.В. Численное моделирование процесса теплопередачи через стеклопакеты с газовым наполнением // Вестник Ижевского государственного технического университета.- 2004, №3.- С. 29-32.

5. Влияние толщины газовой прослойки на термическое сопротивление однокамерного стеклопакета// Басок Б.И., Давыденко Б.В., Новицкая М.П., Гончарук C.M., Недбайло А.Н. // Промышленная теплотехника, 2012, т. 34, №1, C.100-107.

6. Математическое моделирование теплообмена в межстекольном промежутке окна // Грищенко В.В., Низовцев М.И., Терехов В.В., Терехов В.И. // Известия Вузов. Строительство. - 2002. - № 7. - С. 120-127.

7. Численное моделирование теплопереноса через двухкамерный стеклопакет. // Б.И. Басок, Б.В. Давыденко, С.А. Исаев, С.М. Гончарук, Л.Н. Кужель // Инженерно-физический журнал. Том 89, - 2016, №5. С.1288 1295 , г. Минск.

8. МBB № 081/24-0778-11 Метрологія. Опір теплопередаванню крізь огороджувальні конструкції будівель i споруд різного призначення. Методика виконання вимірювань комбінованим тепловізійно-пірометричним методом. ІТТФ НАНУ. - 2011.

9. Патанкар $C$. Численные методы решения задач теплообмена и динамики жидкости. - Москва: Энергоатомиздат, 1984.

10. Пейре Р., Тейлор Т. Д. Вычислительные методы в задачах механики жидкости. Ленинград: Гидрометеоиздат, 1986. 


\section{THE NUMERICAL RESEARCH OF INFLUENCE OF RADIATION AND CONVECTIVE HEAT TRANSFER ON THE HEAT-INSULATING ABILITY OF DOUBLE-CHAMBERED WINDOWS CONSTRUCTIONS}

Basok B.I. ${ }^{1}$, Davydenko B.V. ${ }^{1}$, Kuzhel L.M. ${ }^{1}$, Novikov V.G. ${ }^{1}$, Kalinina M.F. ${ }^{2}$

${ }^{1}$ Institute of Engineering Thermophysics of the National Academy of Sciences of Ukraine,

2a, Zhelyabova str., Kyiv, 03680, Ukraine

${ }^{2}$ National Technical universytet Ukraine "Kyiv Polytechnic Institute named Igor Sikorsky",

Peremoha Avenue, 37, Kiev, 03056, Ukraine

Using the method of numerical modeling, regularities of heat transfer through a double glazing with plain glass and double-chambered glazed windows with a low-emission coating are investigated. Their resistance to heat transfer is determined. The results of numerical modeling made it possible to determine the heat loss levels of the building.

References 10, table 1, figures 7.

Key words: heat transfer; window constructions; numerical modeling; radiation heat transfer; convective heat transfer; double-chambered glazed windows with a low-emission coating.

1. Energy efficiency in regional terms. Problems and prospects. The analytical report. [Electronic resource]. http://www.niss.gov.ua/content/articles/files/energoefektb40dc.pdf (Ukr.)

2. Cabinet of Ministers of Ukraine, the decision of 11 November 2015, the. Number 1228 "National Action Plan for Energy Efficiency until 2020" [Electronic resource], site Verkhovna Rada http://zakon2.rada.gov.ua/laws/show/ n0001824-15/paran2\#n2 (Ukr.)

3. Basok B.I. Goncharuk S.M., Kuzhel L.M. Improving the energy efficiency of buildings by applying modern energy efficient window designs. Proceedings of the 14th All-Ukrainian scientific-technical conference "Actual problems of energy and the environment," Odessa ONAFT, 5-8 October 2016, P. 148-152.

4. Korepanov E.V. Numerical modeling of the heat transfer process through double-glazed windows with gas filling // Bulletin of the Izhevsk State Technical University. 2004, № 3. P. 29 - 32. (Ukr.)

5. Basok B.I., Davydenko B.V., Novytskaya M.P., Goncharuk S.M., Nedbaylo A.N. Effect of Gas-fired tolschynы stratum termycheskoe Resistance to singlechamber Thermopanes. Prom. teplotehnyka, 2012, v. 34, №1, P. 100-107. (Rus.)

6. Grishchenko V.V., Nizovtsev M.I., Terekhov V.V., Terekhov V.I. Mathematical modeling of heat exchange in the inter-glass window gap. Proceedings of Higher Educational Institutions. Building. 2002, No. 7, P. 120-127. (Rus.)

7. B.I. Basok, B.V. Davydenko, S.A. Isaev, S.M. Goncharuk, L.N. Kuzhel. Numerical modeling of heat transfer through a double-chamber glass packet. Engineering and Physics Journal. Vol. 89, 2016, No. 5, P.1288-1295, Minsk. (Rus.)

8. MBB number 081 / 24-0778-11. Metrology. Teploperedavannyu resistance through the building envelope of buildings and structures for various purposes. Methods of measurement combined pirometrychnym-Thermal method. Institute of Engineering Thermophysics NASU. 2011. (Ukr.)

9. Patankar S. Numerical methods for solving problems of heat transfer and fluid dynamics. Moscow, Energoatomizdat, 1984. (Rus.)

10. Peyre R., Taylor T.D. Computational methods in problems of fluid mechanics. Leningrad: Gidrometeoizdat, 1986. (Rus.) 